
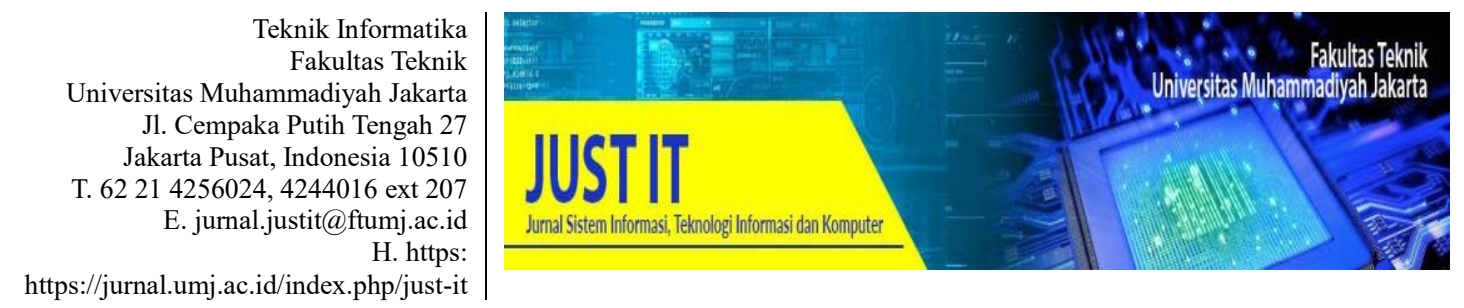

\title{
VISUALISASI MUSEUM MUHAMMADIYAH MENGGUNAKAN TEKNOLOGI AUGMENTED REALITY
}

\author{
Fijaya Dwi Bima Sakti Putra ${ }^{1}$, Rusydi Umar ${ }^{2}$, dan Sunardi ${ }^{3}$ \\ ${ }^{12}$ Magister Teknik Informatika, Universitas Ahmad, ${ }^{3}$ Program Studi Teknik Elektro, Universitas \\ Ahmad Dahlan
}

fijaya1907048016@webmail.uad.ac.id ${ }^{l}$,rusydi@mti.uad.ac.id ${ }^{2}$, sunardi@mti.uad.ac.id ${ }^{3}$

\begin{abstract}
Abstrak
Perkembangan teknologi begitu cepat. Di luar negeri, semakin banyak bermunculan teknologi mutakhir yang sudah diaplikasikan ke publik untuk memudahkan masyarakatnya, seperti Augmented Reality (AR), sudah diterapkan pada banyak hal: pendidikan, pariwisata, advertising, laporan berita, dan lain-lain. Di Indonesia penggunaan AR masih kurang. Padahal penggunaan teknologi AR bisa lebih memudahkan serta membantu visualisasi banyak hal. Pembangunan museum Muhammadiyah di kompleks kampus 4 Universitas Ahmad Dahlan, yang dimulai sejak tahun 2018, sekarang sudah memasuki tahap finalisasi. Dalam rangka memudahkan masyarakat mengenal museum Muhammadiyah serta bermacammacam koleksi yang ada, dibutuhkan media advertising yang dikemas dengan teknologi untuk membuat masyarakat semakin tertarik mengetahui museum Muhammadiyah. Teknologi AR diterapkan pada selebaran media advertising berupa brosur. Masyarakat bisa melakukan scan barcode yang tertera di brosur tersebut sehingga tampak 3D bangunan museum Muhammadiyah serta sebagian koleksi yang ada di sana. Teknologi AR membawa masyarakat memasuki dunia virtual hanya dengan ponsel pintar. AR memerlukan masukan berupa model 3D yang dibuat menggunakan software Blender dan Unity. Model 3D yang sudah di-render kemudian diaplikasikan menggunakan teknologi AR menggunakan ponsel.
\end{abstract}

Kata Kunci: AR, Blender, Unity, 3D, Museum Muhammadiyah

\begin{abstract}
The development of technology is so fast. Overseas, more and more emerging technologies that have been applied to the public to facilitate the community, such as Augmented Reality (AR), have been applied to many things: education, tourism, advertising, news reports, and others. In Indonesia the use of AR is still lacking. Though the use of AR technology can make it easier and help visualize many things. The construction of the Muhammadiyah museum in campus 4 area of Ahmad Dahlan University, which began in 2018, has now entered the finalization stage. In order to make it easier for the public to get to know the Muhammadiyah museum and the various collections available, it requires advertising media that is packed with technology to make people more interested in knowing the Muhammadiyah museum. AR technology is applied to advertising media leaflets in the form of brochures. The public can scan the barcode listed in the brochure so that it looks 3D Muhammadiyah museum buildings and some of the collections there. AR technology brings people
\end{abstract}


into the virtual world only with smart phones. AR requires input in the form of $3 D$ models created using Blender and Unity software. $3 D$ models that have been rendered are then applied using AR technology using mobile phones.

Keywords: AR, Blender, Unity, 3D, Museum Muhammadiyah

\section{PENDAHULUAN}

Perkembangan teknologi yang begitu cepat melahirkan banyak teknologi baru yang lebih membantu dan memudahkan pekerjaan manusia. Teknologi Augmented Reality (AR) hadir sebagai teknologi yang mampu menggabungkan dunia virtual dengan dunia nyata secara realtime menggunakan bantuan ponsel pintar. Ponsel pintar banyak digunakan oleh semua kalangan, mulai dari usia muda hingga usia tua (Boham \& Rondonuwu, 2017) merupakan salah satu penyebab teknologi AR kian diminati.

Teknologi AR dapat menciptakan pengalaman unik yang memperluas peluang dan keterlibatan langsung pengguna (Jamil, 2017). Lahirnya teknologi ini memudahkan penggunanya untuk merasakan sensasi yang berbeda, karena informasi yang bersifat ilustrasi seperti teks, gambar, animasi, suara dan juga video dapat ditampilkan begitu nyata. AR sudah diaplikasikan pada banyak bidang seperti kesehatan, pariwisata, pendidikan dan bisnis.

Implikasi menjamurnya pariwisata budaya, maka museum menjadi mitra penting. Keberadaan museum lebih ditekankan pada fungsi pengalaman (Vol \& Maret, 2019). Museum Muhammadiyah yang dibangun di kompleks kampus 4 (UAD) Yogyakarta yang dibangun sejak tahun 2018 lalu, sekarang sudah mulai tahap finalisasi.

Penyampaian informasi di museum mempengaruhi informasi yang diperoleh pengunjung (Limantara \& Kristianto, 2017). Informasi harus disampaikan dengan cara yang menarik. Brosur berguna bagi museum untuk mempermudah orientasi pengunjung.

Tujuan dari teknologi AR bisa digunakan untuk mengenalkan masyarakat mengenai museum Muhammadiyah serta koleksikoleksi yang dimiliki. Selain itu, penerapan teknologi AR diharap bisa mengajak masyarakat untuk berinteraksi sambil mengenal sejarah yang ada di museum Muhammadiyah.
Aplikasi AR yang telah diterapkan di Banten Lama dapat membantu para pengguna untuk mengenali landmark objek wisata tersebut (Arifitama \& Syahputra, 2018). Aplikasi AR dirancang dengan pendekatan marker based tracking. Rata-rata pengguna memberikan nilai 80 dari 100 mengenai fungsionalitas aplikasi AR tersebut.

Penelitian yang dilakukan di Istana Kadriah, Pontianak telah membuktikan bahwa aplikasi AR berhasil membantuk wisatawan mendapatkan informasi tentang barang sejarah di museum tersebut (Putri, Anra, \& Perwitasari, 2019). Hasil uji User Acceptance Test menunjukkan bahwa aplikasi AR sudah memenuhi aspek visual dan berfungsi sebagaimana mestinya.

Penerapan AR yang dilakukan di museum Bali (Aditya Nugraha, Putra, \& Sukarsa, 2016) berhasil menunjukkan keefektifitasnya. Sebanyak 50 responden menyatakan bahwa aplikasi AR sangat berguna dalam memahami info mengenai koleksi yang ada di museum.

Pembaruan pada perangkat seluler semakin meningkat (Zamroni, Umar, \& Riadi, 2016) karena masyarakat tidak lagi menggunakan ponsel sebagai alat komunikasi saja. Ponsel pintar begitu memudahkan pekerjaan (Wiharto \& Budihartanti, 2017) karena fungsi-fungsinya sudah menyamai dengan personal computer (Umar, Imam Riadi, \& Bashor Fauzan Muthohirin, 2019).

Android menyediakan play store guna memberikan kebebasan untuk para pengembang dalam membuat aplikasi dalam sistem operasi tersebut (Riadi \& Umar, 2017).

Unity3D merupakan software game engine yang sudah sering digunakan dalam pengembangan game dan media berbasis AR. Unity memiliki render engine yang berguna untuk merender 2D atau 3D grafis yang mampu membuat objek 3D berlaku layaknya sebagai benda nyata (Suhendar \& Fernando, 2016).

Vuforia merupakan aplikasi tambahan 
yang dibutuhkan oleh Unity3D berupa AR Software Development Kit (SDK). Fitur-fitur yang dimiliki oleh Vuforia memudahkan pengembang untuk mewujudkan pemikiran mereka tanpa adanya batas secara teknis (Ramadhani \& Saputra, 2017). Vuforia memiliki komponen penting bernama VideoPlayback.Unitypackage yang berguna dalam pembuatan AR di Unity3D (Syafrizal, Rifqo, \& Ardiansyah, 2018).

AR merupakan teknologi yang dapat memvisualisasikan rekayasa digital ke dalam dunia nyata. Rekayasa digital yang sudah berisikan konten audio dan video divisualisasikan dengan real-time. Pengguna akan mendapatkan pengalaman visualisasi yang alami dan menyenangkan (Sindu \& Julianto, 2017).

Blender adalah software opensource yang berfungsi untuk pembuatan $3 D$ model, video editor, sculpting, animation dan rigging. Blender memiliki fitur yang lebih lengkap dari software 3D lainnya. Render engine pada Blender sudah menggunakan Eevee render engine yang kinerjanya cepat. Blender tersedia untuk sistem operasi Windows, Linux dan MacOS (Rori, Sentinuwo, \& Karouw, 2016).

Marker adalah penanda yang digunakan untuk menampilkan objek 3D yang sudah terdaftar pada database marker tersebut. 3D objek bisa divisualisasikan dengan melakukan scanning marker menggunakan kamera.Naskah dipaparkan secara naratif (tanpa penomoran di depan sub judul) dan pemaparan dalam bentuk sub judul dihindari.

\section{METODOLOGI}

Penelitian dilaksanakan di museum Muhammadiyah komplek kampus 4 (UAD) Yogyakarta. Penelitian ini menggunakan beberapa metode dan model, yaitu:

- Observasi dan Interview

Pengumpulan data menggunakan teknik observasi dan interview. Observasi digunakan untuk melihat secara langsung keadaan museum Muhammadiyah serta koleksi yang tersedia. Kemudian dilakukan interview terhadap pihak-pihak terkait pembangunan museum Muhammadiyah untuk mengumpulkan objek-objek yang nantinya akan dibutuhkan oleh sistem.
- Unified Modeling Language (UML)

UML merupakan bahasa standar yang digunakan untuk menggambarkan proses yang terjadi pada aplikasi (Ahmad, Iqbal, Ashraf, Truscan, \& Porres, 2019). Penelitian ini menggunakan use case diagram dan activity diagram.

- Multimedia Development Life Cycle (MDLC)

MDLC merupakan metode yang dibuat khusus untuk pengembangan aplikasi multimedia (Mustika, 2018). Tahapan-tahapan yang ada di metode MDLC ialah concept, design, material collection, assembly dan distribution.

\section{- Flowchart AR}

Flowchart sebagai diagram alir digunakan untuk menjabarkan proses pengujian marker menggunakan aplikasi AR.

Kerangka berpikir dalam penelitian ini diawali dengan melakukan studi awal untuk mencari permasalahan yang terjadi. Setelah itu dilanjutkan dengan penentuan lokasi penelitian dan survey lokasi untuk melihat keadaan museum Muhammadiyah secara langsung. Pengambilan data dari pihak-pihak terkait dalam pembangunan museum Muhammadiyah dilakukan untuk mengumpulkan data berupa bentuk ruangan dan koleksi museum Muhammadiyah. Data yang sudah dikumpulkan kemudian diolah menjadi 3D model dan pada tahap pengembangan aplikasi, model 3D diterapkan ke dalam bentuk aplikasi AR. Aplikasi AR diuji coba menggunakan pengujian black box untuk melihat kegunaan fitur dan menu. Kerangka berpikir dalam penelitian ini bisa dilihat pada Gambar 1. 


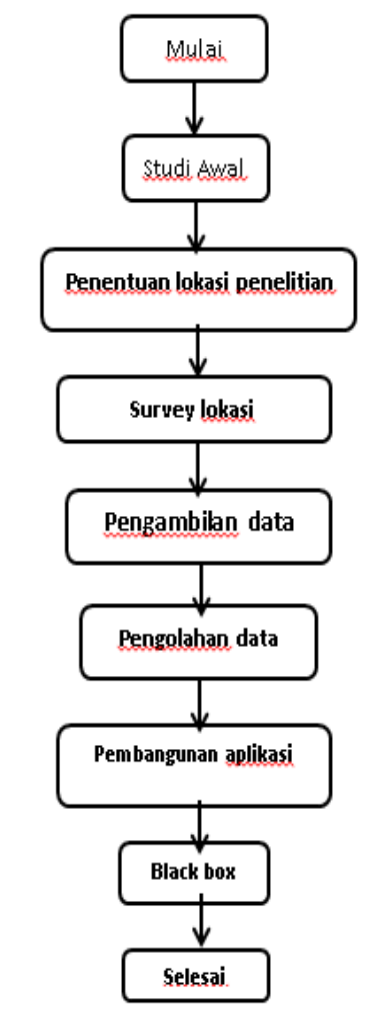

Gambar. 1. Kerangka Berpikir.

Komunikasi antara aplikasi AR dengan dunia luar bisa digambarkan menggunakan use case diagram (Sabharwal, Kaur, \& Sibal, 2017) seperti yang terlihat pada Gambar 2 .

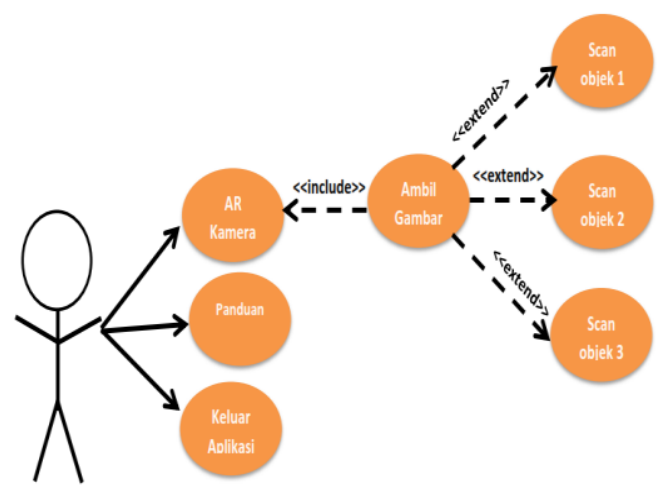

Gambar. 2. Use Case Diagram.

Penggambaran aktifitas dan relasi yang terjadi di aplikasi AR bisa menggunakan activity diagram seperti (Lahon \& Sharma, 2019) yang terlihat pada Gambar 3 .

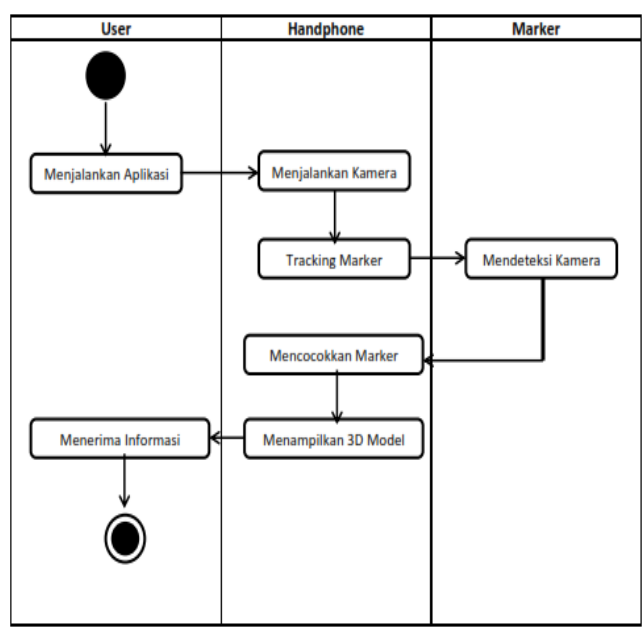

Gambar. 3. Activity Diagram.

Aplikasi AR dibangun menggunakan metode Multimedia Development Life Cycle (MDLC), dengan tahapan concept, design, material collection, assembly, testing, dan distribution. Tahapan ini bisa dilihat pada Gambar 4.

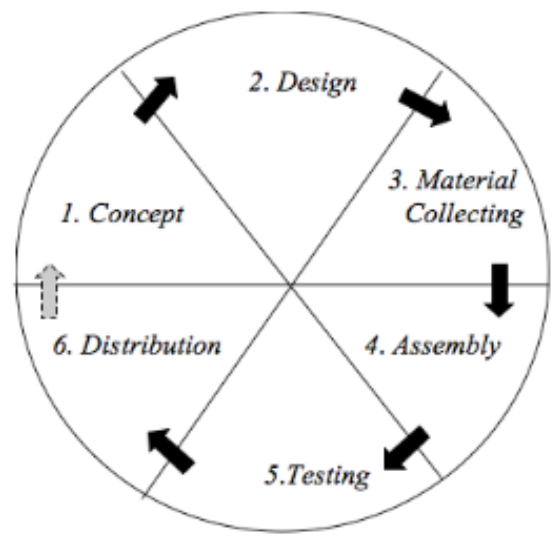

Gambar. 4. Multimedia Development Life Cycle.

Desain flowchart diperlukan untuk menggambarkan langkah-langkah dan urutan prosedur suatu program (Muntahanah, Toyib, \& Ansyori, 2017). Flowchart pada penelitian ini digunakan untuk menguji marker yang tersedia di brosur museum Muhammadiyah. Dimulai dengan melakukan input marker objek ke dalam brosur. Kamera di aplikasi AR diarahkan ke marker tersebut. Apabila marker valid atau berhasil maka muncul objek 3D jika marker tidak valid atau tidak berhasil maka dilakukan identifikasi ulang pada marker melalui kamera. Desain flowchart aplikasi pada penelitian ini ditampilkan pada Gambar 5. 


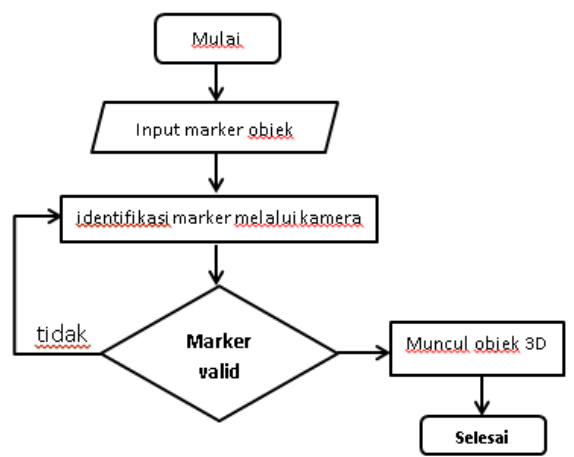

Gambar. 5. Desain Flowchart Pengujian AR.

\section{HASIL DAN PEMBAHASAN}

Tujuan pembuatan aplikasi AR ditentukan di tahap concept. Aplikasi AR dibuat untuk memudahkan masyarakat mengetahui info mengenai museum Muhammadiyah.

Pada tahap design dibuat spesifikasi mengenai perangkat keras dan perangkat lunak yang digunakan untuk membuat aplikasi AR seperti yang terlihat pada Tabel 1 .

TABEL 1

KEBUTUHAN PERANGKAT KERAS DAN PERANGKAT LUNAK

\begin{tabular}{|l|l|}
\hline Perangkat keras & Perangkat lunak \\
\hline Laptop Asus X441S & Blender 2.81 \\
\hline RAM 2 GB & Unity 2019.2.15 \\
\hline Windows 10 64bit & Vuforia \\
\hline $\begin{array}{l}\text { VGA Integrated Intel } \\
\text { HD }\end{array}$ & Inkscape 0.92.4 \\
\hline
\end{tabular}

Pengumpulan bahan-bahan pendukung untuk pengembangan media AR, seperti bangunan museum Muhammadiyah dan koleksinya dilakukan di tahapan material collecting.

Bahan-bahan yang telah dikumpulkan diolah pada tahapan assembly. Objek dan bahan multimedia disatukan ke dalam aplikasi AR. Objek yang diolah pada penelitian ini ialah koleksi sejarah dan bentuk bangunan museum Muhammadiyah. Objek tersebut dikonversi menjadi model 3D menggunakan software Blender.

Tesktur, bentuk dan warna objek model 3D dibuat menyerupai bentuk aslinya tetapi untuk volume dan tinggi model 3D disesuaikan dengan resolusi dari ponsel pintar. Proses pengolahan objek menjadi model 3D bisa dilihat pada Gambar 6.

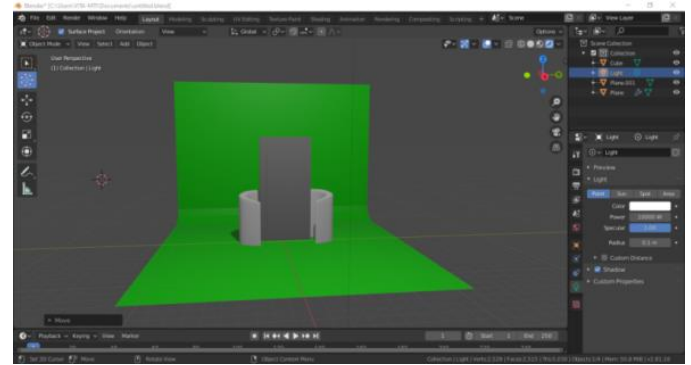

Gambar. 6. Proses Modelling Objek.

Objek 3D yang sudah di-modelling selanjutnya masuk ke tahap rendering menggunakan Eevee di Blender. Hasil rendering bisa dilihat pada Tabel 2 .

TABEL 2

\begin{tabular}{|l|l|l|}
\hline No & Model 3D & $\begin{array}{l}\text { Moterangan } \\
\text { keseluruhan } \\
\text { bangunan } \\
\text { museum } \\
\text { Muhammadiyah }\end{array}$ \\
\hline 1 & & $\begin{array}{l}\text { Monumen } \\
\text { Syuhada Fii } \\
\text { Sabilillah Kauman }\end{array}$ \\
\hline 3 & & $\begin{array}{l}\text { Kitab Fiqih Jilid } \\
\text { III" terbitan } \\
\text { Taman Poestaka } \\
\text { Muhammadiyah } \\
\text { edisi 1343 H. H. } \\
\text { (1925 } \\
\text { Djokjakarta }\end{array}$ \\
\hline 4 & & $\begin{array}{l}\text { Gapura kampong } \\
\text { Kauman }\end{array}$ \\
\hline
\end{tabular}

Hasil rendering berupa model 3D diolah menggunakan Unity yang fungsinya membangun dan menggabungkan aplikasi AR dengan model 3D. Aplikasi Vuforia digunakan untuk mendaftarkan model 3D ke database marker.

Marker berfungsi sebagai wadah untuk memunculkan model 3D. Di penelitian ini, marker yang digunakan adalah marker berbentuk foto. Marker diletakkan di brosur sebagai media yang bisa digunakan oleh pengguna untuk memperoleh informasi mengenai museum Muhammadiyah dengan 
cara yang interaktif. Salah satu marker berbentuk foto dapat dilihat pada Gambar 7 .

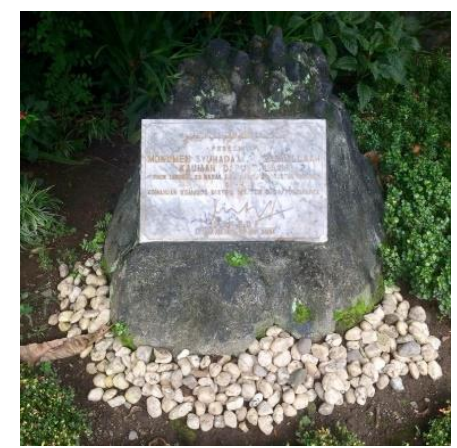

Gambar. 7. Marker Berbentuk Foto.

Brosur didesain menggunakan aplikasi desain grafis bernama Inkscape. Desain brosur dapat dilihat pada Gambar 8.

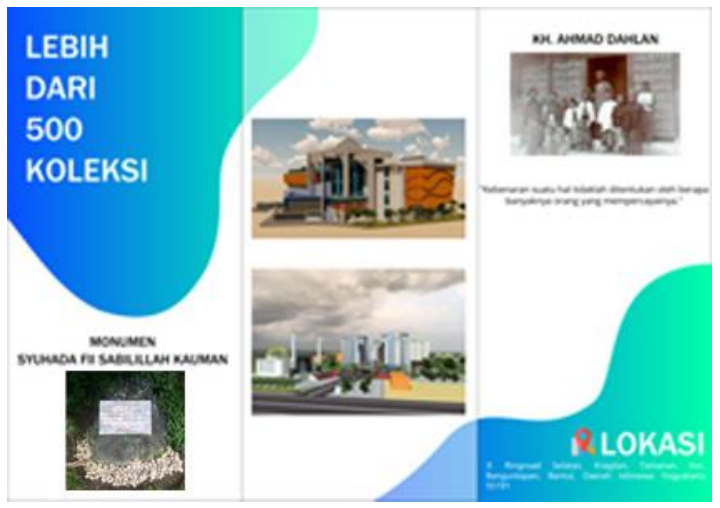

Gambar. 8. Marker di Brosur.

Brosur dengan style tiga-lipatan ini memuat informasi mengenai museum Muhammadiyah seperti lokasi, bentuk bangunan, dan koleksi-koleksi yang dimiliki. Di sisi kanan brosur terdapat petunjuk mengenai penggunaan aplikasi AR dan link download aplikasi.

Tampilan menu aplikasi AR dibuat sederhana agar tidak membingungkan pengguna. Pada awal tampilan tertulis petunjuk yang bertuliskan "Arahkan kamera ke foto yang tersedia di brosur museum Muhammadiyah". Pada bagian bawah aplikasi disediakan tombol "next" yang bisa digunakan oleh pengguna untuk memulai proses scan marker. Tampilan aplikasi bisa dilihat pada Gambar 9.

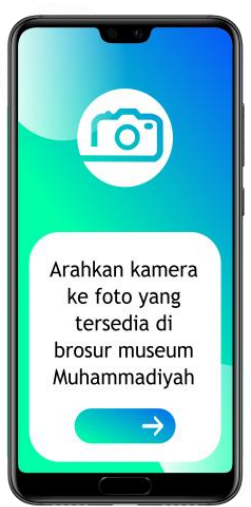

Gambar 9. Tampilan Aplikasi

Proses scanning marker bisa dilakukan oleh pengguna dengan mengarahkan kamera ponsel pintar ke foto yang tersedia di brosur. Seperti terlihat pada Gambar 10.

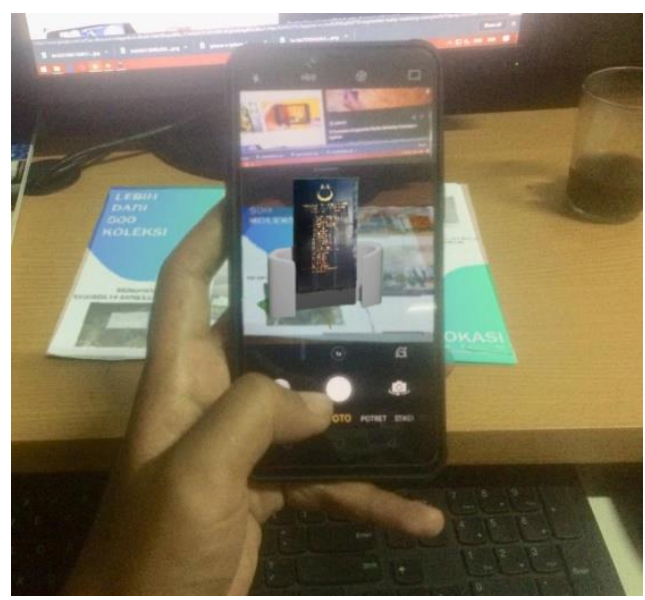

Gambar 10. Hasil Scan Marker

Pada tahap testing, aplikasi AR diuji menggunakan uji coba black box. Pengujian black box digunakan untuk mengetahui fungsi menu aplikasi AR apakah kinerjanya sudah sesuai dengan yang diharapkan (Adami \& Budihartanti, 2016). Pengujian black box bisa dilihat pada Tabel 3.

TABEL 3.

UJI BLACK BOX

\begin{tabular}{|c|l|c|l|c|}
\hline $\begin{array}{c}\text { N } \\
\text { o }\end{array}$ & Pengujian & Aksi & $\begin{array}{l}\text { Hasil yang } \\
\text { Diharapkan }\end{array}$ & $\begin{array}{c}\text { Hasil } \\
\text { Uji }\end{array}$ \\
\hline 1 & $\begin{array}{l}\text { Tampilan } \\
\text { Menu } \\
\text { Utama }\end{array}$ & & $\begin{array}{l}\text { Scene menu } \\
\text { utama } \\
\text { muncul }\end{array}$ & Sesuai \\
\hline 2 & $\begin{array}{l}\text { Tombol } \\
\text { kamera }\end{array}$ & Sentuh & $\begin{array}{l}\text { Scene } \\
\text { berpindah } \\
\text { ke halaman } \\
\text { scan marker }\end{array}$ & Sesuai \\
\hline 3 & $\begin{array}{l}\text { Tombol } \\
\text { keluar }\end{array}$ & Sentuh & $\begin{array}{l}\text { Aplikasi AR } \\
\text { keluar }\end{array}$ & Sesuai \\
\hline
\end{tabular}




\begin{tabular}{|c|c|c|c|c|}
\hline 4 & $\begin{array}{l}\text { Menampil } \\
\text { kan objek } \\
\text { 3D } \\
\text { gedung } \\
\text { museum } \\
\text { Muhamm } \\
\text { adiyah }\end{array}$ & $\begin{array}{l}\text { Mengar } \\
\text { ahkan } \\
\text { Kamera } \\
\text { ke } \\
\text { marker }\end{array}$ & $\begin{array}{l}\text { Objek 3D } \\
\text { gedung } \\
\text { museum } \\
\text { Muhammad } \\
\text { iyah }\end{array}$ & Sesuai \\
\hline 5 & $\begin{array}{l}\text { Menampil } \\
\text { kan objek } \\
\text { 3D } \\
\text { koleksi } \\
\text { museum }\end{array}$ & $\begin{array}{l}\text { Mengar } \\
\text { ahkan } \\
\text { Kamera } \\
\text { ke } \\
\text { marker }\end{array}$ & $\begin{array}{l}\text { Objek 3D } \\
\text { tampil di } \\
\text { atas marker }\end{array}$ & Sesuai \\
\hline
\end{tabular}

Uji kompatibilitas dilakukan dengan melakukan instalasi aplikasi AR pada beberapa versi Android (Nursyadid, Nuraldi, \& Pamungkas, 2018) seperti terlihat pada Tabel 4.

TABEL 4

UJI KOMPATIBILITAS

\begin{tabular}{|l|c|c|}
\hline \multicolumn{1}{|c|}{$\begin{array}{c}\text { Nama } \\
\text { Perangkat }\end{array}$} & $\begin{array}{c}\text { Versi } \\
\text { Android }\end{array}$ & Hasil \\
\hline $\begin{array}{l}\text { Samsung } \\
\text { Galaxy TAB 3 }\end{array}$ & 4.0 & $\begin{array}{c}\text { Aplikasi berjalan } \\
\text { dengan lancar }\end{array}$ \\
\hline Galaxy Note 1 & 5.1 & $\begin{array}{c}\text { Aplikasi berjalan } \\
\text { dengan lancar }\end{array}$ \\
\hline Oppo F5 & 7.1 & $\begin{array}{c}\text { Aplikasi berjalan } \\
\text { dengan lancar }\end{array}$ \\
\hline
\end{tabular}

Pengujian jarak, kamera dan marker dilakukan untuk mengetahui keakuratan kamera mendeteksi dan mengenal marker (Aprianto, Firdaus, Armin, Studi, \& Informatika, 1945) seperti terlihat pada Tabel 5.

TABEL 5.

\begin{tabular}{|c|c|c|c|} 
PENGUJIAN JARAK, KAMERA DAN MARKER \\
\hline Jarak & $\begin{array}{c}\text { Sudut } \\
\text { kemiringa } \\
\text { n kamera }\end{array}$ & Pencahayaan & $\begin{array}{c}\text { Berhasil } \\
\text { /Tidak }\end{array}$ \\
\hline 4 & $0^{\circ}$ & $\begin{array}{c}\text { Cahaya } \\
\text { lampu, gelap }\end{array}$ & Berhasil \\
\hline 4 & $0^{\circ}$ & $\begin{array}{c}\text { Sinar } \\
\text { matahari, } \\
\text { berawan }\end{array}$ & Berhasil \\
\hline 8 & $0^{\circ}$ & $\begin{array}{c}\text { Cahaya } \\
\text { lampu, gelap }\end{array}$ & Berhasil \\
\hline 8 & $0^{\circ}$ & $\begin{array}{c}\text { Sinar } \\
\text { matahari, } \\
\text { berawan }\end{array}$ & Berhasil \\
\hline 12 & $0^{\circ}$ & $\begin{array}{c}\text { Cahaya } \\
\text { lampu, gelap }\end{array}$ & Berhasil \\
\hline 12 & $0^{\circ}$ & $\begin{array}{c}\text { Sinar } \\
\text { matahari, } \\
\text { berawan }\end{array}$ & Berhasil \\
\hline 27 & $0^{\circ}$ & $\begin{array}{c}\text { Cahaya } \\
\text { lampu, gelap }\end{array}$ & Berhasil \\
\hline 27 & $0^{\circ}$ & $\begin{array}{c}\text { Sinar } \\
\text { Berhasil }\end{array}$ \\
\hline
\end{tabular}

\begin{tabular}{|c|c|c|c|}
\hline & & $\begin{array}{c}\text { matahari, } \\
\text { berawan }\end{array}$ & \\
\hline 50 & $0^{\circ}$ & $\begin{array}{c}\text { Cahaya } \\
\text { lampu, gelap }\end{array}$ & Berhasil \\
\hline 50 & $0^{\circ}$ & $\begin{array}{c}\text { Sinar } \\
\text { matahari, } \\
\text { berawan }\end{array}$ & Berhasil \\
\hline 4 & $45^{\circ}$ & $\begin{array}{c}\text { Cahaya } \\
\text { lampu, gelap }\end{array}$ & Berhasil \\
\hline 4 & $45^{\circ}$ & $\begin{array}{c}\text { Sinar } \\
\text { matahari, } \\
\text { berawan }\end{array}$ & Berhasil \\
\hline 8 & $45^{\circ}$ & $\begin{array}{c}\text { Cahaya } \\
\text { lampu, gelap }\end{array}$ & Berhasil \\
\hline 8 & $45^{\circ}$ & $\begin{array}{c}\text { Sinar } \\
\text { matahari, } \\
\text { berawan }\end{array}$ & Berhasil \\
\hline 12 & $45^{\circ}$ & $\begin{array}{c}\text { Cahaya } \\
\text { lampu, gelap }\end{array}$ & Berhasil \\
\hline 12 & $45^{\circ}$ & $\begin{array}{c}\text { Sinar } \\
\text { matahari, } \\
\text { berawan }\end{array}$ & Berhasil \\
\hline 27 & $45^{\circ}$ & $\begin{array}{c}\text { Cahaya } \\
\text { lampu, gelap }\end{array}$ & Berhasil \\
\hline 27 & $45^{\circ}$ & $\begin{array}{c}\text { Sinar } \\
\text { matahari, } \\
\text { berawan }\end{array}$ & Berhasil \\
\hline 50 & $45^{\circ}$ & $\begin{array}{c}\text { Cahaya } \\
\text { lampu, gelap }\end{array}$ & Berhasil \\
\hline 50 & $45^{\circ}$ & $\begin{array}{c}\text { Sinar } \\
\text { matahari, } \\
\text { berawan }\end{array}$ & Berhasil \\
\hline 4 & $70^{\circ}$ & $\begin{array}{c}\text { Cahaya } \\
\text { lampu, gelap }\end{array}$ & Berhasil \\
\hline 4 & $70^{\circ}$ & $\begin{array}{c}\text { Sinar } \\
\text { matahari, } \\
\text { berawan }\end{array}$ & Berhasil \\
\hline 8 & $70^{\circ}$ & $\begin{array}{c}\text { Cahaya } \\
\text { lampu, gelap }\end{array}$ & Berhasil \\
\hline 8 & $70^{\circ}$ & $\begin{array}{c}\text { Sinar } \\
\text { matahari, } \\
\text { berawan }\end{array}$ & Berhasil \\
\hline 12 & $70^{\circ}$ & $\begin{array}{c}\text { Cahaya } \\
\text { lampu, gelap }\end{array}$ & Berhasil \\
\hline 12 & $70^{\circ}$ & $\begin{array}{c}\text { Sinar } \\
\text { matahari, } \\
\text { berawan }\end{array}$ & Berhasil \\
\hline 27 & $70^{\circ}$ & $\begin{array}{c}\text { Cahaya } \\
\text { lampu, gelap }\end{array}$ & Berhasil \\
\hline 27 & $70^{\circ}$ & $\begin{array}{c}\text { Sinar } \\
\text { matahari, } \\
\text { berawan }\end{array}$ & Berhasil \\
\hline 50 & $70^{\circ}$ & $\begin{array}{c}\text { Cahaya } \\
\text { lampu, gelap }\end{array}$ & Berhasil \\
\hline 50 & $70^{\circ}$ & $\begin{array}{c}\text { Sinar } \\
\text { matahari, } \\
\text { berawan }\end{array}$ & Berhasil \\
\hline
\end{tabular}




\section{KESIMPULAN}

Berbagai penelitian mengenai AR yang diterapkan dalam bidang pembangunan dan pariwisata telah menunjukkan bahwa teknologi AR sangat bermanfaat. Kesimpulan yang dapat diambil bahwa penelitian ini baru memasuki tahap perancangan yang diharapkan nantinya aplikasi AR Museum Muhammadiyah ini dapat membantu masyarakat dalam mengerti mengenai rancangan serta koleksi yang nantinya akan ditampilkan.

\section{DAFTAR PUSTAKA}

Adami, F. Z., \& Budihartanti, C. (2016). Penerapan Teknologi Augmented Reality pada Media Pembelajaran Sistem Pencernaan Berbasis Android. Teknik Komputer AMIK BSI, 2(1), 122131. Retrieved from http://ejournal.bsi.ac.id/ejurnal/index.ph $\mathrm{p} / \mathrm{jtk} /$ article/viewFile/370/279

Aditya Nugraha, I. G., Putra, I. K. G. D., \& Sukarsa, I. M. (2016). Rancang Bangun Aplikasi Augmented Reality Museum Bali Berbasis Android Studi Kasus Gedung Karangasem dan Gedung Tabanan. Lontar Komputer: Jurnal Ilmiah Teknologi Informasi, 7(2), 93. https://doi.org/10.24843/lkjiti.2016.v07. i02.p03

Ahmad, T., Iqbal, J., Ashraf, A., Truscan, D., \& Porres, I. (2019). Model-based testing using UML activity diagrams: A systematic mapping study. Computer Science Review, 33(July), 98-112. https://doi.org/10.1016/j.cosrev.2019.07 .001

Aprianto, B., Firdaus, M., Armin, A. P., Studi, P., \& Informatika, T. (1945). TEKNOLOGI AUGMENTED REALITY SEBAGAI MEDIA PENGENALAN MOBIL BESERTA MODIFIKASI BAGIAN EKSTERIOR.

Arifitama, B., \& Syahputra, A. (2018). Mobile Augmented Reality Pengenalan Situs Sejarah Kawasan Banten Lama dengan Metode Marker Based Tracking. JTERA (Jurnal Teknologi Rekayasa), 3(2), 255. https://doi.org/10.31544/jtera.v3.i2.2018 .255-260

Boham, A., \& Rondonuwu, S. A. (2017). Penggunaan Smartphone Dalam Menunjang Aktivitas Perkuliahan Oleh Mahasiswa Fispol Unsrat Manado. EJournal Acta Diurna, VI(2), 1-15.

Jamil, M. (2017). Pemanfaatan Teknologi Virtual Reality ( VR ) di Perpustakaan. Jurnal Informatika, (2017), 99-113.

Lahon, M., \& Sharma, U. (2019). Complexity assessment based on UML-activity diagram. International Journal of Recent Technology and Engineering, 8(2), 2391-2397.

https://doi.org/10.35940/ijrte.B1596.078 219

Limantara, O., \& Kristianto. (2017). Pengaruh Interior terhadap Perilaku Pengunjung Museum House of Sampoerna Surabaya. 5(2), 811-819.

Muntahanah, M., Toyib, R., \& Ansyori, M. (2017). Penerapan Teknologi Augmented Reality Pada Katalog Rumah Berbasis Android (Studi Kasus Pt. Jashando Han Saputra). Pseudocode, 4(1), 81-89. https://doi.org/10.33369/pseudocode.4.1 $.81-89$

Mustika. (2018). Rancang Bangun Aplikasi Sumsel Museum Berbasis Mobile Menggunakan Metode Pengembangan Multimedia Development Life Cycle (MDLC). Jurnal Mikrotik, 8(1), 1-14. Retrieved from https://ojs.ummetro.ac.id/index.php/mik rotik/article/view/746/548

Nursyadid, D., Nuraldi, N., \& Pamungkas, W. (2018). Aplikasi Pembelajaran Chord Gitar Berbasis. 4(2), 659-668.

Putri, N. D., Anra, H., \& Perwitasari, A. (2019). Aplikasi Augmented Reality Pengenalan Barang Sejarah pada Istana Kadriah Kota Pontianak. Jurnal Sistem Dan Teknologi Informasi (JUSTIN), 7(1), $\quad 7$. https://doi.org/10.26418/justin.v7i1.271 85 
Ramadhani, T., \& Saputra, D. (2017). Penerapan Virtual Reality Untuk Mempromosikan Istano Basa Pagaruyuang Batusangkar Sebagai Tempat Wisata Budaya (Vol. 4, pp. 129142). Vol. 4, pp. 129-142.

Riadi, I., \& Umar, R. (2017). Identification Of Digital Evidence On Android' $s$. International Journal of Computer Science and Information Security, 15(5), 3-8.

Rori, J., Sentinuwo, S. R., \& Karouw, S. (2016). Perancangan Aplikasi Panduan Belajar Pengenalan Ortodonsia Menggunakan Animasi 3D. Jurnal Teknik Informatika, 8(1), 3-7. https://doi.org/10.35793/jti.8.1.2016.12 299

Sabharwal, S., Kaur, P., \& Sibal, R. (2017). Empirical and Theoretical Validation of a Use Case Diagram Complexity Metric. International Journal of Information Technology and Computer Science, 9(11), 35-47. https://doi.org/10.5815/ijitcs.2017.11.04

Sindu, E., \& Julianto, A. (2017). Brosur Apartemen berbasis Android dengan Teknologi Augmented Reality. Multinetics, $3(2), \quad 7$. https://doi.org/10.32722/vol3.no2.2017. pp 7-11

Suhendar, A., \& Fernando, A. (2016). Aplikasi Virtual tour Berbasis Multimedia Interaktif Menggunakan Autodesk 3Ds Max. ProTekInfo, 3(1), 30-35.

Syafrizal, A., Rifqo, M. H., \& Ardiansyah, M. (2018). Aplikasi Pengenalan Tempat Wisata Propinsi Bengkulu Menggunakan Teknologi Augmented Reality (Video Playback) Berbasis Android. Journal of Technopreneurship and Information System (JTIS), 1(1), 5053. https://doi.org/10.36085/jtis.vli2.23

Umar, R., Imam Riadi, \& Bashor Fauzan Muthohirin. (2019). Live Forensics of Tools on Android Devices for Email Forensics. TELKOMNIKA (Telecommunication Computing
Electronics and Control), 17(4), 18031809.

https://doi.org/10.12928/telkomnika.v17 i4.11748

Vol, I., \& Maret, B. (2019). IKRAITHEKONOMIKA Vol 2 No 1 Bulan Maret 2019 125. 2(1), 125-136.

Wiharto, A., \& Budihartanti, C. (2017). Aplikasi Mobile Augmented Reality Sebagai Media Pembelajaran Pengenalan Hardware Komputer Berbasis Android. PROSISKO: Jurnal Pengembangan Riset Dan Observasi Sistem Komputer, 4(2), 17-24. https://doi.org/10.2777/58454

Zamroni, G. M., Umar, R., \& Riadi, I. (2016). Analisis Forensik Aplikasi Instant Messaging Berbasis Android. 2(1), 102105. Retrieved from http://ars.ilkom.unsri.ac.id 